\title{
Profitability as a business goal: the multicriteria approach to the ranking of the five largest Croatian banks
}

\author{
Višnja Vojvodić Rosenzweig, Hrvoje Volarević and Mario Varović \\ Zagrebačka škola ekonomije i managementa, Zagreb, Croatia
}

\section{Abstract}

\begin{abstract}
Background: The ranking of commercial banks is usually based on using a single criterion, the size of assets or income. A multicriteria approach allows a more complex analysis of their business efficiency. Objectives: This paper proposes the ranking of banks based on six financial criteria using a multicriteria approach implementing a goal programming model. The criteria are classified into three basic groups: profitability, credit risk and solvency. Methods/Approach: Business performance is evaluated using a score for each bank, calculated as the weighted sum of relative values of individual indicators. Results: In the process of solving the corresponding goal programming problem, the weights are calculated. It is assumed that the goal of each bank is the highest profitability. Because of the market competition among banks, the weights of indicators depend on the performance of each bank. This method is applied to the five biggest Croatian banks (ZABA, PBZ, ERSTE, RBA and HYPO). Conclusion: For the observed period (2010), the highest priority is given to profitability and then to credit risk. The ranking is achieved by using a multicriteria model.
\end{abstract}

Key words: Commercial banks, bank ranking, profitability, multicriteria modelling, goal programming. JEL Classification: G32

Paper type: Research article

Recieved: 20, April, 2012

Revised: 20, June, 2012

Accepted: 28, June, 2012

\section{Višnja Vojvodić Rosenzweig, Hrvoje Volarević, Mario Varović}

Citation: Vojvodić Rosenzweig, V., Volarević, H., Varović, M. (2012). "Profitability as a business goal: the multicriteria approach to the ranking of the five largest Croatian banks", Business Systems Research, Vol. 3, No. 1, pp. 37-48.

DOI: 10.2478/v10305-012-0006-0

\section{Introduction}

The goal of every business subject in a market environment is increasing its profit, in order to increase the wealth of the owner (Dayananda et al., 2002). This goal is achieved by increasing its income and/or reducing its costs. Doing this directly increases profitability. In practice, business profitability is measured by financial profit margin indicators and return on capital investment indicators (Horngren and Oliver, 2010). Values of a couple different profit margin indicators depend primarily on the outcome of the income statement. For instance, gross profit margin, operating profit margin, the profit margin before income taxes and the profit margin after income taxes. Also there are different return on capital investment indicators, like return on assets, return on long-term capital and return on equity.

Commercial banks are specific business subjects that operate in an extremely competitive financial sector. They have a key role in the process of being a financial intermediary in which they collect an excess of monetary assets and place them to those that need financing. A long-term goal of every bank is to achieve the highest level of business profitability. The success of a bank's business is observed by the height of its realized profit (Nguyen, 2011). To achieve the planned level of business profitability it is important to take into account important banking determinants like solvency and their safety, i.e. properly administer credit risk. Next to profitability, first and most important long-term goal, a bank can gravitate towards 
certain short-term goals like increasing its market share. It should be noted that in the analysis of the success of different commercial banks, different financial indicators are used. They are adapted to the specifics of the banking sector and therefore differ in relation to classical indicators that are used in the real sector (Toby, 2011).

Commercial banks in this paper are chosen based on their specific roles in Croatian economy. They belong to the so-called bank-centric financial system. The Croatian banking sector consists of thirty commercial banks, the majority of which are in foreign ownership, mostly Italian, Austrian, French and Hungarian banks. Because of their dominant position, two largest commercial banks in Croatia can be singled out. They are Zagrebačka banka (ZABA) and Privredna banka Zagreb (PBZ). The ranking of commercial banks has usually been done using only single criterion (size of assets or capital, or realized income or profit respectively). Based on total balance assets data up to 31st December 2010, the first five banks in Croatia, next to ZABA and PBZ are Erste \& Steiermarkische bank (ERSTE), Raiffeisenbank Austria (RBA) and Hypo-Alpe-Adria-bank (HYPO). These five banks encompass three quarters of the total balance assets of the Croatian banking sector.

The purpose of the research in this paper is to introduce a multicriteria approach by applying a goal programming model in order to rank commercial banks. The results imply specific conclusions directed towards the ranking of specific banks on the chart of the top commercial banks in Croatia. The research in this paper is also directed toward analyzing financial reports for 2010 and the calculation of the six chosen indicators divided into three basic groups: profitability, credit risk and solvency (Croatian National Bank, 2011). The profitability indicators analyse the return of invested capital into the business process. On the other hand, credit risk indicators are specific for the banking sector since they grade the quality and the safety of banking placements. Solvency, the third group of indicators, is represented by only one indicator that analyses the relationship between private and foreign assets which are at the banks disposal. It is assumed that the strategy of every observed bank for the given period is profitability. All the above mentioned indicators serve towards achieving the goal, which is high profitability. On the other hand, commercial multicriteria performance of a bank is represented by its score. The score is calculated as the weighted sum of relative values of individual indicators. The weights assigned to every indicator show the importance of the specific indicator. A goal programming problem is formulated in order to assess the weights that reflect interaction between these banks on the financial market. Two criteria are used for assessing the weights in order to have the smallest deviation from the imposed goal. The first model uses the augmented Chebyshev criterion in which the deviations are uniformly allocated, so that not a single bank has a large deviation from the goal. The second model uses least square deviation. If the assumptions mentioned above are fulfilled, the resulting analysis offers us an insight into business activity of the banks. From the resulting relative values of indicators and the solution of the model, the goal is not the same for every bank. Moreover, the assessments of relative data, while changing the assumed goal differ significantly. Although one bank is evaluated as the bank with the best business performance, regardless of the assumed goal, the ranking of the remaining banks change. This paper differs in relation to other articles that use the same methodology: Garcia, Guijarro and Moya, (2010) and Vojvodić Rosenzweig, Volarević and Varović (2011). It differs in the sense that this paper observes banks, whose goal is high profitability and who are mutually competitive. The multicriteria business score, assigned to every bank, serves these particular goals.

The structure of this paper encompasses four chapters. After the introduction, in which the purpose and the methodology of the research are explained, the second chapter explains all six criteria, including the calculation of the values. In the third chapter, the goal programming model is formulated, and it is applied to the described problem. The last chapter contains a discussion and the final observations where the assumptions from the introduction are confirmed.

\section{Selection of criteria}

Ranking of commercial banks is a classic problem of multicriteria decision-making. In the first place, it is necessary to select the criteria on the basis of the ranking of the banks in a descending order (from the best to the worst). In this paper six individual criteria have been chosen, categorized in three fundamental groups (profitability, credit risk, and solvency) as follows:

1. Return on average assets - ROAA represents one of the most well-known indicators of profitability that is often used not only in the banking sector, but also in the real sector (Jewell, 2011). The value of this indicator is obtained from the next relation: 


\section{$\mathrm{X} 1=$ Return on average assets (ROAA) $=$ profit before taxation / average assets of the bank}

Profit before taxation can be found in the Income statement (P\&L), while the average assets of the bank are calculated as the arithmetical mean of the balance sheet's positions on the asset side for two consecutive business years (in this case for the years 2009 and 2010). The obtained values are expressed as percentages, and are desirable to be as high as possible for each bank.

2. Return on average equity - ROAE also represents a well-known profitability indicator, as well as Return on average assets (Blocher, Chen and Lin, 2002). The value of this indicator is obtained as follows:

\section{$\mathrm{X} 2$ = Return on average equity (ROAE) = profit after taxation / average equity of the bank}

Profit after taxation is the final entry of the Income statement, while the average equity of the bank is calculated in the same way as the average assets of the bank (arithmetical mean of the balance sheet's positions of the equity for the two sequential business years). The obtained values are also expressed as percentages, and are desirable to be as high as possible for each bank.

3. Income from interest bearing assets and expenses on interest bearing liabilities represents a specific indicator of profitability that is solely applied to the banking sector (Croatian National Bank, 2011). The value of this indicator is obtained as follows:

\section{$\mathrm{X} 3$ = Income from interest bearing assets and expenses on interest bearing liabilities $=$ (interest income / average interest bearing assets) / (interest expenses / average interest bearing liabilities)}

Interest income and interest expenses represent the initial positions in the Income statement of every business bank because they define the financial result that is derived from basic banking activity receiving deposits and lending loans. Interest bearing assets are the total of all positions on the asset side of the balance sheet that represent the ground for calculating active interest, by which banks' income is generated. On the other hand, interest bearing liabilities are the total of all positions on the liability side of the balance sheet as the ground for calculating passive interest that make banks' expenditures. The obtained values are expressed as absolute values and it is desirable that the obtained results of this ratio be as high as possible in order to confirm the profitability of banks dealings.

4. Coverage represents the indicator commonly used in banks for credit risk evaluation (Croatian National Bank, 2011). The value of this indicator is obtained as follows:

\section{$\mathrm{X} 4$ = Coverage $=$}

(total of investments impairment + provisions) / (total of investments + contingent liabilities)

The numerator of the ratio consists of the total of investments impairment and provisions, where the impairment stands for the cumulative of all recognized losses for bad and doubtful loans that are not expected to be repaid, that is reimbursed, while the term provisions refers to the balance sheet position on the liability side that is recognized in the banks expenses as future observed and estimated liabilities (for example provisions for legal actions, that is lawsuits filed against the bank). The denominator of the ratio consists of the total of investments comprised divided by the total of all balance sheet positions on the asset side of the bank that represent the basis for generating income, and the other part of the denominator relates to contingent liabilities that are, as a rule, booked on the off-balance sheet, and consist of given guarantees and open letters of credit as typical banking affairs. The obtained values are expressed as percentages, and it is desirable that the obtained results of this ratio should be as high as possible, which implies that the bank management is aware of possible credit risk in business activities and of the necessity for its anticipation.

5. Quality of investments represents an indicator that pertains to the credit risk assessment, as well as coverage, because it assesses the percentage of bank investments that can be reimbursed. The value of this indicator is obtained as follows: 


\section{X5 $=$ Quality of investments $=$ \\ 1 - (total of investments impairment / total of investments}

The equation listed above puts in ratio two positions from the asset side of the bank's balance sheet. The obtained values are expressed as percentages and their maximum value is $100 \%$, which means that all the bank's investments can be repaid and that there is no need for investment impairment. Taking into account the existing risk when making credit investments, this situation should not be expected to be realistic.

6. Debt to equity ratio represents, in the banking sector, a specific solvency indicator based on expressed results. The debt to equity ratio is a measure of the relationship between the capital contributed by creditors and the capital contributed by shareholders. It usually spans between $50 \%$ and $150 \%$ for the real sector, which means that most business firms are financed equally with private and foreign capital. The situation is different with banks based on their fundamental function, which assumes that they primarily adopt foreign capital. That is why their debt to equity ratio is considerably ranger than the real sector (Atrill and McLaney, 2006). The value of this indicator is obtained as follows:

\section{X6 $=$ Debt to equity ratio $=$ total bank debt / average bank capital}

The values are obtained exclusively from the passive side of the balance sheet. The obtained values are expressed as percentages, and it is desirable that the obtained results of this ratio should be as small as possible. Although the debt in the banking sector is significantly higher, it is still preferred to be in line with its own capital.

Based on the former formulas, the calculated values of all six individual criteria $(X 1, X 2, X 3, X 4, X 5$ and $X 6)$ for the five selected banks (ERSTE, HPB, HYPO, POBA and RBA), and all the obtained results are presented in the following decision-making table (Table 1):

Table 1

The values of six individual indicators categorized into three basic groups (profitability, credit risk, and solvency) for the five selected banks

\begin{tabular}{|l|c|c|c|c|c|c|}
\hline \multirow{2}{*}{ Banks } & \multicolumn{3}{|c|}{ Profitability indicators } & \multicolumn{2}{c|}{ Credit risk indicators } & $\begin{array}{c}\text { Solvency } \\
\text { indicators }\end{array}$ \\
\cline { 2 - 7 } & $\mathbf{X 1}$ & $\mathbf{X 2}$ & $\mathbf{X 3}$ & $\mathbf{X 4}$ & $\mathbf{X 5}$ & $\mathbf{X 6}$ \\
\hline $\mathbf{1 . ~ Z A B A}$ & $1,65 \%$ & $9,03 \%$ & 2,1152 & $3,40 \%$ & $96,31 \%$ & $577,37 \%$ \\
\hline $\mathbf{2 .}$ PBZ & $1,57 \%$ & $8,54 \%$ & 2,3136 & $3,14 \%$ & $96,60 \%$ & $565,87 \%$ \\
\hline 3. ERSTE & $1,52 \%$ & $10,55 \%$ & 2,2679 & $4,37 \%$ & $95,65 \%$ & $769,49 \%$ \\
\hline 4. RBA & $1,13 \%$ & $6,77 \%$ & 2,1882 & $2,85 \%$ & $96,97 \%$ & $625,30 \%$ \\
\hline $\mathbf{5 . ~ H Y P O}$ & $0,72 \%$ & $3,56 \%$ & 1,7827 & $5,71 \%$ & $93,90 \%$ & $507,23 \%$ \\
\hline Total & $6,59 \%$ & $38,45 \%$ & 10,67 & $19,47 \%$ & $479,43 \%$ & $3045,26 \%$ \\
\hline
\end{tabular}

Source: Author results

All the criteria in the model, except for the last one (X6 - debt to equity ratio) are benefit criteria. This means that it is in the bank's interest to maximize their values. In that case the decision table must contain either only benefit or only cost criteria. Accordingly the only cost criteria X6 will be treated as a benefit criteria by taking into account its reciprocal values for all five banks (1/X6). The results are represented in the following decision-making table (Table 2): 
Table 2

The values of six individual benefit indicators categorized into three basic groups (profitability, credit risk, and solvency) for the five selected banks

\begin{tabular}{|c|c|c|c|c|c|c|}
\hline \multirow{2}{*}{ Banks } & \multicolumn{3}{|c|}{ Profitability } & \multicolumn{2}{|c|}{ Credit risk } & \multirow{2}{*}{$\begin{array}{c}\text { Solvency } \\
1 / \text { X6 }\end{array}$} \\
\hline & $\mathrm{X} 1$ & $\mathrm{X} 2$ & $\mathrm{X} 3$ & $\mathrm{X} 4$ & $\times 5$ & \\
\hline 1. ZABA & $1,65 \%$ & $9,03 \%$ & 2,1152 & $3,40 \%$ & $96,31 \%$ & $17,32 \%$ \\
\hline 2. PBZ & $1,57 \%$ & $8,54 \%$ & 2,3136 & $3,14 \%$ & $96,60 \%$ & $17,67 \%$ \\
\hline 3. ERSTE & $1,52 \%$ & $10,55 \%$ & 2,2679 & $4,37 \%$ & $95,65 \%$ & $13,00 \%$ \\
\hline 4. RBA & $1,13 \%$ & $6,77 \%$ & 2,1882 & $2,85 \%$ & $96,97 \%$ & $15,99 \%$ \\
\hline 5. HYPO & $0,72 \%$ & $3,56 \%$ & 1,7827 & $5,71 \%$ & $93,90 \%$ & $19,71 \%$ \\
\hline Total & $6,59 \%$ & $38,45 \%$ & 10,67 & $19,47 \%$ & $479,43 \%$ & $83,69 \%$ \\
\hline
\end{tabular}

Source: Author results

Even in the former decision making table most of the criteria are represented as percentages, not all the benefit criteria are represented in identical measuring units. This is why we transform the benefit criteria. Percentage transformation is used, because it leads to proportional changes in the results of benefit criteria. The results are represented in the following decision-making table (Table 3):

Table 3

The transformed values of six individual benefit indicators categorized into three basic groups (profitability, credit risk, and solvency) for the five selected banks

\begin{tabular}{|l|c|c|c|c|c|c|}
\hline \multirow{2}{*}{ Banks } & \multicolumn{3}{|c|}{ Profitability } & \multicolumn{2}{c|}{ Credit risk } & Solvency \\
\cline { 2 - 7 } & $\mathbf{X 1}$ & $\mathbf{X 2}$ & $\mathbf{X 3}$ & $\mathbf{X 4}$ & $\mathbf{X 5}$ \\
\hline 2. PBBA & 0,2504 & 0,2349 & 0,1983 & 0,1746 & 0,2009 & 0,2069 \\
\hline 3. ERSTE & 0,2382 & 0,2221 & 0,2169 & 0,1613 & 0,2015 & 0,2111 \\
\hline 4. RBA & 0,2307 & 0,2744 & 0,2126 & 0,2244 & 0,1995 & 0,1553 \\
\hline 5. HYPO & 0,1715 & 0,1761 & 0,2051 & 0,1464 & 0,2023 & 0,1911 \\
\hline Total & 0,1093 & 0,0926 & 0,1671 & 0,2933 & 0,1959 & 0,2356 \\
\hline
\end{tabular}

Source: Author results

\section{Goal programming model and implementation}

Multicriteria business performance of each bank will be evaluated using a score calculated as the weighted sum of relative values of individual indicators (Garcia et al., 2010). Score Si of bank i, i $=1, \ldots, 5$ depends on the chosen indicators. Since the indicators are multidimensional, they are reduced to their relative values in the decision table. The problem becomes one dimensional, and calculating the score makes sense. The Score depends on the weights assigned to every indicator. The weights signify the importance of every indicator; it is a non negative number. For computational reasons, the sum of the weights is equal to one. When choosing different weights, the score of a bank changes. Moreover, if we observe the single criterion problem for the five commercial banks in Croatia, where the only criterion is the indicator ROAA, the highest ranked bank is ZABA. If we choose ROAE, as the only indicator, then the highest ranked bank 
is ERSTE. Finally, by choosing solvency, the highest rated bank is HYPO. The banks themselves are oriented towards the capital market and the performance of competing banks. Every bank has a business strategy, by which it hopes to achieve its goals.

We assume that the goal for every bank is profitability that is observed from one of the three profitability indicators. In that sense the goal programming problem will be formulated. The notations in the model are as follows:

1. $\quad i-$ bank $i, i=1, \ldots, 5$.

2. $\quad j-$ indicator, $j=1, \ldots, 6$.

3. $w j$ - weight of indicator $j, j=1, \ldots, 6$.

4. $x i j$ - relative value of indicator $j$ of bank $i, i=1, \ldots, 5 ; j=1, \ldots, 6$.

5. $\mathrm{si}$-score of bank $\mathrm{i}, \mathrm{i}=1, \ldots, 5$.

6. $g i$-goal of bank $i, i=1, \ldots, 5$.

7. $\mathrm{di}^{-}-$underattainment of goal $\mathrm{i}, \mathrm{i}=1, \ldots, 5$.

8. di+- overattainment of goal $i, i=1, \ldots, 5$.

$$
S_{i}=\sum_{j=1}^{6} w_{j} x_{i j}, i=1, \ldots, 5
$$

Si, score of bank $i$, is defined as follows:

The score can be defined differently for more detail Triantaphyyllou (2000).

Then we label $(i=1, \ldots, 5)$ for everyone of the five banks ( 1 - ZABA; 2 - PBZ; 3 - ERSTE; 4 - RBA; 5 - HYPO).

Since the first three indicators define the profitability measure of a bank, the goal gi of bank $i$ is:

$$
g_{i}=\max \left\{x_{i j}: j=1,2,3\right\}, i=1,2,3,4,5
$$

The general problem of goal programming is finding the solution as close as possible to the assigned goal (Ignizio and Romero, 2003). In this case, it is necessary to find indicator weights for which the deviation of the score and the goal is the smallest. The distance of the goal $\mathrm{g}=(\mathrm{gl}, \mathrm{g} 2, \mathrm{~g} 3, \mathrm{~g} 4, \mathrm{~g} 5)$ and the score $\mathrm{S}=$ $($ S1, S2, S3, S4, S5) is usually defined by a metric. Two different metrics are used. First we formulate the goal programming problem (Pa) using the augmented Chebyshev metric (9), also known as the DinkelbachIsermann, for more detail Sawaragi, Nakayama and Tanino (1985).

The mathematical model is formulated:

$$
\min \left(\max \left\{\left|g_{i}-S_{i}\right|: i=1, \ldots, 5\right\}+\alpha \sum_{i=1}^{5}\left(d_{i}^{-}+d_{i}^{+}\right)\right)
$$




$$
S_{i}+d_{i}^{-}-d_{i}^{+}=g_{i}, i=1, \ldots, 5
$$

$$
\begin{gathered}
S_{i}-\sum_{j=1}^{6} w_{j} x_{i j}=0, i=1, \ldots, 5 . \\
\sum_{j=1}^{6} w_{j}=1 \\
d_{i}^{-}, d_{i}^{+}, w_{j} \geq 0, i=1, \ldots, 5 ; j=1, \ldots, 6 .
\end{gathered}
$$

The parameter a is a small positive number. The mathematical model has the following constraints. The value of the score can deviate from the assigned goal, as it is defined in the group of constraints (10). The group of constraints (11) define the score. The constraint (12) relates to normed values. The objective function (9) in the given model has the optimal solution where at least one of the variables di- or dit is equal to zero, i.e.:

$$
d_{i}^{-} d_{i}^{+}=0, i=1, \ldots, 5 \text {. }
$$

This statement can be checked in the book Sawaragi et al. (1985).

Now, we define:

$$
y=\max \left\{\left|g_{i}-S_{i}\right|: i=1, \ldots, 5\right\}
$$

Because of (13) and (14) it follows:

$$
y=\max \left\{\left|g_{i}-S_{i}\right|: i=1, \ldots, 5\right\} \geq d_{i}^{-}+d_{i}^{+}, i=1, \ldots, 5
$$


The problem ( $\mathrm{Pa}$ ) is transformed into an equivalent problem (Pya) using (15):

$$
\begin{gathered}
\min \left(y+\alpha \sum_{i=1}^{5}\left(d_{i}^{-}+d_{i}^{+}\right)\right) \\
S_{i}+d_{i}^{-}-d_{i}^{+}=g_{i}, i=1, \ldots, 5 . \\
S_{i}-\sum_{j=1}^{6} w_{j} x_{i j}=0, i=1, \ldots, 5 . \\
\sum_{j=1}^{6} w_{j}=1 \\
d_{i}^{-}+d_{i}^{+} \leq y, i=1, \ldots, 5 . \\
d_{i}^{-}, d_{i}^{+}, w_{j} \geq 0, i=1, \ldots, 5 ; j=1, \ldots, 6 . \\
y \geq 0
\end{gathered}
$$

The problem (Pya) is solved for the values of the parameter $a=1, a=0,1$ and $a=0,01$. For every value of a, the same optimal solution is obtained. It is shown in the following tables:

Table 4

Obtained indicator weights for the problem (Pya)

\begin{tabular}{|c|c|c|c|c|c|}
\hline W1 & W2 & W3 & W4 & W5 & W6 \\
\hline 0,1356 & 0,5388 & 0 & 0,1142 & 0,2115 & 0 \\
\hline
\end{tabular}

Source: Author results

Table 5

Bank scores for the problem (Pya)

\begin{tabular}{|c|c|c|c|c|}
\hline ZABA & PBZ & ERSTE & RBA & HYPO \\
\hline 0,2229 & 0,2130 & 0,2469 & 0,1776 & 0,1396 \\
\hline
\end{tabular}

Source: Author results

The assumption about the goal of every bank gives us the most important indicator, ROAE whose weight is the highest. The bank with the largest score is the bank with the highest indicator.

Now we change the HYPO banks goal. We assume that its goal is solvency for the observed year. The goal of the rest for the banks, profitability, remains the same. Because of the new assumption, g5 is the only parameter we change in the model. We solve the following model where the goals are: 


$$
g_{i}=\max \left\{x_{i j}: j=1,2,3\right\}, i=1,2,3,4 .
$$

$$
g_{5}=x_{56}
$$

The problem is solved for the values of the parameter $a=1, a=0,1$ and $a=0,01$. For every value of $a$, the same optimal solution is obtained. It is shown in the following tables:

Table 6

Obtained indicator weights for the problem (Pya) with a change of parameter g5

\begin{tabular}{|c|c|c|c|c|c|}
\hline W1 & W2 & W3 & W4 & W5 & W6 \\
\hline 0,2739 & 0,1948 & 0 & 0,4384 & 0,0929 & 0 \\
\hline
\end{tabular}

Source: Author results

Table 7

Bank scores for the problem (Pya) with a change of parameter g5

\begin{tabular}{|c|c|c|c|c|}
\hline ZABA & PBZ & ERSTE & RBA & HYPO \\
\hline 0,2096 & 0,1979 & 0,2336 & 0,1643 & 0,1948 \\
\hline
\end{tabular}

Source: Author results

Risk has become a more important criterion, right next to profitability. HYPO has improved its business score but ERSTE is still at first place.

The second goal programming problem is formulated using the same labels, but the criterion is the least square deviation. The problem (P2):

$$
\begin{gathered}
\min \sum_{i=1}^{5}\left(\left(d_{i}^{-}\right)^{2}+\left(d_{i}^{+}\right)^{2}\right) \\
S_{i}+d_{i}^{-}-d_{i}^{+}=g_{i}, i=1, \ldots, 5 . \\
S_{i}-\sum_{j=1}^{6} w_{j} x_{i j}=0, i=1, \ldots, 5 . \\
\sum_{j=1}^{6} w_{j}=1 \\
d_{i}^{-}, d_{i}^{+}, w_{j} \geq 0, i=1, \ldots, 5 ; j=1, \ldots, 6 .
\end{gathered}
$$


We can notice that the models (P2) and (Pa) differ only with the objective function.

Problem (P2) is solved with the same two assumptions as the problem (Pa). First we assume that the goal of every bank is profitability (8) and the optimal solution is:

Table 8

Obtained indicator weights for the problem (P2)

\begin{tabular}{|c|c|c|c|c|c|}
\hline W1 & W2 & W3 & W4 & W5 & W6 \\
\hline 0,11 & 0,56 & 0 & 0,12 & 0,22 & 0 \\
\hline
\end{tabular}

Source: Author results

Table 9

Bank scores for the problem (P2)

\begin{tabular}{|c|c|c|c|c|}
\hline ZABA & PBZ & ERSTE & RBA & HYPO \\
\hline 0,22 & 0,21 & 0,25 & 0,22 & 0,14 \\
\hline
\end{tabular}

Source: Author results

Now we solve the same problem (P2) only we assume that HYPO has a different goal with the parameter values gi, the same as in (16) and (17), and we obtain the following optimal solution:

Table 10

Obtained indicator weights for the problem (P2) with a change of parameter g5

\begin{tabular}{|c|c|c|c|c|c|}
\hline W1 & W2 & W3 & W4 & W5 & W6 \\
\hline 0,27 & 0,20 & 0 & 0,44 & 0,09 & 0 \\
\hline
\end{tabular}

Source: Author results

Table 11

Bank scores for the problem (Pya) with a change of parameter g5

\begin{tabular}{|c|c|c|c|c|}
\hline ZABA & PBZ & ERSTE & RBA & HYPO \\
\hline 0,21 & 0,20 & 0,23 & 0,21 & 0,19 \\
\hline
\end{tabular}

Source: Author results

The solution of the given mathematical models estimates the score of every bank. The bank with the highest score is the bank that is ranked first. Depending on the criteria and assumed goals of the banks we obtained different rankings. Ranked first is always the ERSTE bank. Independent from the criteria and the assumed goals, because ERSTE has always the highest score.

\section{Discussion and conclusion}

Multicriteria ranking of the observed commercial banks, reflected in the results of the goal programming model shows us the relative relationship between them. The chosen sample is representative for the croatian banking sector. With the assumption about the goal of every bank and based on six indicators, the results of the goal programming model gives us the ranking of the largest Croatian commercial banks. The implementation of such a mathematical model has allowed us to reach certain conclusions.

The analysis of business performance for Croatia's five largest commercial banks for 2010 was made with the assumption that the goal for every bank is highest profitability. With the given assumption and chosen indicators, the highest weights have been assigned to profitability indicators. The profitability indicators are 
ROAA, ROAE and income from interest bearing assets and expenses on interest bearing liabilities. The most important profitability indicator is ROAE. The calculation has been done for two different criteria, for two different objective functions, in which we measure the deviation from the imposed goals.

The first goal programming model uses the augmented Chebyshev as an objective function. The highest ranked bank in this goal programming model is the ERSTE bank. The profitability indicators for the ERSTE bank were the highest, i.e. ERSTE had the highest business score, therefore was ranked the highest. Next in the rankings were ZABA, then PBZ and RBA. The bank with the lowest rating was HYPO. Based on the relative indicator values for the given period, HYPO did business with small risk and small profitability, but with high solvency. In the next step, we changed the goal for HYPO from profitability to solvency. A new ranking has been achieved, with new score values. In this situation HYPO has improved its rating in relation to other banks. While the ranking of the first three banks remains the same, HYPO achieves fourth position, in front of RBA (1. ERSTE; 2. ZABA; 3. PBZ; 4. HYPO; 5. RBA).

The second goal programming model implements the Euclidian metric as the objective function. As with the first model, ERSTE has the highest business score in the second model, while ZABA is second. Third place is reserved for RBA, fourth for PBZ, and the last place for HYPO. In relation to the first model, the only difference in the ranking is the ranking of the third and fourth ranked bank, RBA changed places with PBZ. If we change the goal of HYPO, as we did in the last mode, from profitability to solvency, the final ranking did not change. All the banks retained their ranking (1. ERSTE; 2. ZABA; 3. RBA; 4. PBZ; 5. HYPO). The only change came from the value of their scores, which in this case did not affect the bank ranking. Regardless of the change of the goal of one bank, in both cases the first place is held by the ERSTE bank. So with the both goal programming models, ERSTE has the highest business score, regardless on the choice of criteria with which we measure the deviation from the imposed goals. This way we obtained the final ranking of the five biggest commercial banks in Croatia. In the financial sector, a mathematical multicriteria programming model represents an alternative approach in the measuring business success and the ranking of business subjects.

The main limitation of this research is seen primarily in the fact that it is conducted for only one business year. In order to get a complete picture about the workings of five biggest commercial banks in Croatia, it would be necessary to make an analysis for a longer time period. This way, a long-term strategy of every bank could be monitored and an estimated business performance could be achieved for a longer time period. Furthermore, other financial indicators that are used in the banking sector could have been used in this paper, i.e. liquidity indicators or productivity indicators.

Future related research could include widening of the sample of commercial banks in Croatia, i.e. ten biggest banks, or introduce a larger amount of financial indicators to the given mathematical model. Also, consideration should be given to the possibility of using different objective functions in the multicriteria model of goal programming.

\section{Literature}

1. Atrill, P., McLaney, E. (2006). Accounting and Finance for Non-Specialists, 5th ed., Harlow: Prentice Hall.

2. Croatian National Bank (2011), "Banks Bulletin", available at: http://www.hnb.hr/publikac/bilten-obankama/ebilten-o-bankama-23.pdf (7 May 2012).

3. Blocher, E. J., Chen, K. H., Lin, T. W. (2002). Cost Management: A Strategic Emphasis, 2nd ed., New York: McGraw-Hill/Irwin.

4. Dayananda, D., Irons, R., Harrison, S., Herbohn, J., Rowland, P. (2002). Capital Budgeting: Financial Appraisal of Investment Projects, Cambridge: Cambridge University Press.

5. Garcia, F., Guijarro F., Moya I. (2010), "Ranking Spanish savings banks: A multicriteria approach“, Matematical and Computer Modelling, Vol. 52, No. 7-8, pp. 1058-1065.

6. Horngren, C. T., Oliver, M. S. (2010). Managerial Accounting, Upper Saddle River, New Jersey: Pearson Prentice Hall.

7. Ignizio, J. M., Romero, C. (2003), „Goal Programming“, in Bidgoli, H. (Ed.), Encyclopedia of Information Systems, Academic Press, San Diego, Vol. 2, pp. 489-500.

8. Jewell, J. (2011), "What is Your ROA? An Investigation of the Many Formulas for Calculating Return on Assets", Academy of Educational Leadership Journal, Vol. 15, Special No., pp. 79-91.

9. Nguyen, J. (2011), "Market Concentration and other Determinants of Bank Profitability: Evidence from Panel Data", International Research Journal of Finance \& Economics, Vol. 6, No. 70, pp. 7-19.

10. Sawaragi, Y., Nakayama, H., Tanino, T. (1985). Theory of Multiobjective Optimization, Orlando: Academic Press.

11. Toby, A. J. (2011), "Modelling Financial Fragility and Bank Profitability in an International Context", International Journal of Business Insights \& Transformation, Vol. 4, No. 2, pp. 15-24. 
12. Triantaphyyllou, E. (2000). Multi-Criteria Decision Making Methods: A Comparative Study, Dordrecht: Kluwer Academic Publishers.

13. Vojvodić Rosenzweig, V., Volarević, H., Varović, M. (2011), „A Goal Programming Approach to Ranking Banks", in Zadnik Stirn, L., Žerovnik, J., Povh, J., Drobne, S., Lisec, A. (Eds), Proceedings of the 11 th International Symposium on Operational Research (SOR 2011), Slovenian Society Informatika - Section for Operational Research, Dolenjske Toplice, pp. 149-155.

\section{About the authors}

Višnja Vojvodić Rosenzweig is a retired professor from the Faculty od Economics and Business. For the lasł 38 years has been teaching Mathematics, Operational Research, Quantitative Methods, Multicriteria decision making. She has obtained her PhD from The Faculty of Science of the University of Zagreb, Mathematical Department. Author can be contacted at vojvodic.visnja@gmail.com

Hrvoje Volarević is a professor at the Zagreb School of Economics and Management, Accounting Department. For the last nine years has been teaching the accounting subjects and Mathematics for Economists and Managers at the ZSEM undergraduate program. Also, for the last five years has been teaching Financial Statements Analysis at the ZSEM graduate MBA program. In 2010 has obtained a Doctorate Degree at the Faculty of Economics in Split with a specialization in managerial accounting and corporate finance. From 1997 is continuously employed at the Croatian National Bank, from 2001 in Accounting Department as a senior accountant. Author can be contacted at hrvoje.volarevic@zsem.hr

Mario Varović obtained a Masters Degree from the Faculty of Economics in Zagreb with a specialization in accounting, audit \& finance in 2011 . In 1995 graduated from the Faculty of Economics in Zagreb with a major in finance. For the last eight years has been teaching the accounting subjects at the Zagreb School of Economics and Management in graduate and post-graduate programs. From 1997 continuously employed at the Croatian National Bank as a Head of Central Accounting Division. Author can be contacted at mario.varovic@zsem.hr 